\title{
Synthetic versus tissue-engineered implants for joint replacement
}

${ }^{1}$ School of Mechanical Engineering, University of Birmingham, Edgbaston, Birmingham, B15 2TT, UK

${ }^{2}$ Department of Bio-Medical Physics and Bio-Engineering, University of Aberdeen, Foresterhill, Aberdeen, AB25 2ZD, UK

\begin{abstract}
Human synovial joints are remarkable as they can last for a lifetime. However, they can be affected by disease that may lead to destruction of the joint surface. The most common treatment in the advanced stages of joint disease is artificial joint replacement, where the diseased synovial joint is replaced with an artificial implant made from synthetic materials, such as metals and polymers. A new technique for repairing diseased synovial joints is tissue engineering where cells are used to grow replacement tissue. This paper explores the relative merits of synthetic and tissue-engineered implants, using joint replacement as an example. Synthetic joint replacement is a well-established procedure with the advantages of early mobilisation, pain relief and high patient satisfaction. However, synthetic implants are not natural tissues; they can cause adverse reactions to the body and there could be a mismatch in mechanical properties compared to natural tissues. Tissue-engineered implants offer great potential and have major advantages over synthetic implants as they are natural tissue, which should ensure that they are totally biocompatible, have the correct mechanical properties and integrate well with the existing tissue. However, there are still many limitations to be addressed in tissue engineering such as scaling up for production, bioreactor design, appropriate regulation and the potential for disease to attack the new tissue-engineered implant.
\end{abstract}

Key words: Articular cartilage, cells, joint replacement, implant, tissue engineering, synthetic.

\section{INTRODUCTION}

Human synovial joints are remarkable as they can last for a lifetime. However, they can be affected by disease that may lead to destruction of the joint surface, resulting in pain and disability for the sufferer. One of the major successes in healthcare is artificial joint replacement, where the diseased synovial joint is replaced with an implant made from synthetic materials, such as metals and polymers (Hukins et al. 1999). A new technique used for repairing diseased or damaged synovial joints is tissue engineering, where cells are used to grow replacement natural tissue (Berthiaume and Yarmush 2000). Tissue engineering is widely predicted to be a growth sector of biotechnology (Lysaght et al. 1998) with the potential to supplant many synthetic joint replace-

Corresponding author:

D. E. T. Shepherd

Tel: 0121414 4266; Fax: 01214143958

Email: d.e.shepherd@bham.ac.uk ment implant devices. The aim of this paper is to compare the relative merits of synthetic joint replacement implants with tissue-engineered articular cartilage. It is not the intention of the article to provide a state-of-the-art review of either tissue engineering or joint replacement implants, as these types of article are common, e.g. see Hunziker (2002), Martin et al. (2007), McMinn and Daniel (2006), Nesic (2006), Park et al. (2000), Shin and Lee (2007), and Temenoff and Mikos (2000). However, no research has attempted to compare the techniques of joint replacement implants with tissue engineering from an engineering point of view of mass producing a product.

\section{HUMAN SYNOVIAL JOINTS}

Human synovial joints, such as the hip, knee and fingers, enable articulation between two bone ends. The synovial joint comprises articular cartilage, bone and synovial fluid. Articular cartilage is the thin tissue that covers the bone ends and plays an important role in providing the excellent tribological characteristics of synovial joints (Unsworth 
1991; Shepherd and Seedhom 1999b). The structure of articular cartilage consists of a few (about $1 \%$ by volume) cells (chondrocytes) and an abundant extracellular matrix which comprises collagen, noncollagenous proteins, protoeoglycan and water (Shepherd and Seedhom 1997; Hukins et al. 1999; Temenoff and Mikos 2000).

Human joints of the lower limb, such as the hip and knee, are subjected to multiples of body weight (typically 2-3 times for walking) during locomotion over a million times a year (Seedhom and Wallbridge 1985; Bergmann et al. 2001; Costigan et al. 2002). Small joints, such as fingers, although not weight bearing, are flexed over a million times a year (Joyce and Unsworth 2000). Despite the severe conditions that human synovial joints operate under, they can last for a lifetime. However, synovial joints can be affected by disease, such as osteoarthritis or inflammatory arthritis (e.g. rheumatoid arthritis), and in the advanced stages of the disease this leads to destruction of the articular cartilage joint surface, resulting in great pain, disability and a reduced quality of life for the sufferer. Osteoarthritis is characterised by loss of articular cartilage from the joint surface, with thickening of the subchondral bone and formation of bony outgrowths (Dieppe et al. 1985b). With inflammatory arthritis, as well as destruction of the joint surface, there is extensive damage to the soft tissues surrounding the joint, such as ligaments and tendons, and in the latter stages of the disease this results in severe deformity (Dieppe et al. 1985a; Hart et al. 2004). Articular cartilage has a low capability for self-repair, since it has few cells (van der Kraan et al. 2002) and, therefore, the most common treatment in the advanced stages of joint disease is artificial joint replacement with a synthetic implant.

\section{SYNTHETIC JOINT REPLACEMENT IMPLANTS}

One of the major advances in healthcare in the 20th century was the introduction of artificial joint replacement, where the diseased synovial joint is replaced with an artificial implant made from synthetic materials. The hip joint will be used as an example of a joint replacement implant. Conventional joint replacement of the hip involves the surgical removal of the femoral head, broaching of the femur to create a space for the implant stem of the femoral component, and reaming of the acetabulum to create space for the acetabular cup. The femoral and acetabular components are then fitted to give a ball-on-socket articulation. Conventional hip replacements have a cobalt chrome molybdenum alloy femoral component articulating against an ultra high molecular weight polyethylene acetabular cup (Park et al. 2000). These implants can have a survivorship for 20 years or longer (Berry et al. 2002). Other material combinations, such as metal-on-metal (cobalt chrome molybdenum alloy against itself) and ceramic-on-ceramic (alumina against itself) have also become available (Sedel and Raould 2007; Vassiliou et al. 2007). Recently, particularly in younger patients, hip resurfacing has become popular, where the diseased joint is resurfaced with a metal-on-metal joint (Daniel et al. 2004).

Fixation of a synthetic joint replacement implant can be done using bone cement (where polymethylmethacrylate cement acts as a filler between the implant and the bone), an interference fit (where there is a press fit between the implant and the bone) or bone ingrowth (where the implant has a porous layer that bone grows into).

The replacement of small joints (such as the wrist and fingers) has generally been with a one-piece elastomer implant, although articulating implants have also been developed (Beevers and Seedhom 1993; Shepherd and Johnstone 2002).

A potential alternative to the use of joint replacement implants made from synthetic materials is tissueengineered implants.

\section{TISSUE-ENGINEERED JOINT REPLACEMENT IMPLANTS}

Tissue engineering is a rapidly developing field in which cells are used to grow replacement tissue for diseased or damaged tissues (Berthiaume and Yarmush 2000). This can take the form of implanting a scaffold which will be invaded by existing cells in the body, or culturing cells in a laboratory, growing them on a scaffold and implanting the scaffold/cell assembly (tissue construct) into the body (Berthiaume and Yarmush 2000; Seedhom et al. 2007). Scaffolds can be made from a variety of materials, such as natural polymers (e.g. collagen) or bio-resorbable polymers (such as polycaprolactone) that break down in the body and will be replaced by the growing tissue (Hutmacher 2000; van der Kraan et al. 2002; Frenkel and Di Cesare 2004).

Instead of using synthetic joint replacement implants, diseased articular cartilage in synovial joints could be replaced with tissue-engineered articular cartilage. A variety of methods for tissue engineering articular cartilage have been reviewed earlier (Temenoff and Mikos 2000; Hunziker 2002). A technique, known as autologous chondrocyte transplantation, takes a small biopsy of chondrocytes from the patient. Over a number of weeks the chondrocytes are expanded in a laboratory, until the cell density is around 30 million per $\mathrm{ml}$. The cells are then implanted into the patient in the degenerative area of the joint surface, and a membrane stitched over the top of the cells (Brittberg et al. 1994; Brittberg 2007). A commercially available version of this technique, which has Food and Drug Administration approval, is Carticel, which is available for the repair of articular cartilage defects on the femur (Kielpinski et al. 2005). Results have shown the technique to be effective (Micheli et al. 2006; Manfredini et al. 2007). However, there have been a number of adverse events, such as graft delamination (Wood et al. 2006). Most current research is concentrating on the use of a scaffold to which the cells can attach and grow in the laboratory, before the tissue construct is implanted into a patient. Autologous chondrocyte transplantation, which involves the use of a scaffold, has 
also been investigated clinically and the results show clinical improvement (Behrens et al. 2006; Nehrer et al. 2006).

\section{SYNTHETIC VERSUS TISSUE-ENGINEERED JOINT REPLACEMENT IMPLANTS}

\section{Introduction}

Synthetic joint replacement is a well-established procedure for treating diseased synovial joints, with the main advantages being that there is early mobilisation, pain relief and a high patient satisfaction (Orbell et al. 1998). However, synthetic joint replacement is not without its limitations and problems. A tissue-engineered implant has the major advantage over conventional synthetic implants, as it is a natural tissue that is being used to replace the diseased tissue. A natural tissue is likely to be totally biocompatible, have the correct mechanical properties and integrate well with the existing tissue. However, tissue engineering has many limitations that need to be addressed. The relative merits of synthetic and tissue-engineered joint replacement implants will be made in the following sections.

\section{Mechanical properties}

Synthetic implants for joint replacement are not natural tissues and the response of the body is to treat them as harmful. Therefore, it is essential that synthetic materials are biocompatible, that is, they do not cause an adverse reaction from the body such as inflammation (Hukins et al. 1999). A further problem with synthetic materials is that they have different mechanical properties to natural tissues. For example, the stem of a hip implant that fits into the femur is generally made from cobalt chrome molybdenum alloy, with a Young's modulus of $230 \mathrm{GPa}$, whereas the natural cortical bone that the implant fits into has a Young's modulus of around 17 GPa (Park 2000). This leads to reduced loading conditions on the cortical bone which can cause stress shielding, leading to bone resorption and implant loosening (Joshi et al. 2000).

A tissue-engineered implant has the major advantage over conventional synthetic implants as it is a natural tissue that is being used to replace the diseased tissue. A natural tissue is likely to have the correct mechanical properties and integrate well with the existing tissue. However, at present the quality and durability of tissue-engineered articular cartilage is not satisfactory(Hunziker 2002; Gao et al. 2007).

\section{Disease}

One major problem with osteoarthritis and inflammatory arthritis is that the aetiology of the diseases is not fully understood and a great deal of research is still being undertaken to understand these diseases. If the disease is still present in the synovial joint, it may affect any tissueengineered articular cartilage that is implanted into the body. Thus, the new tissue-engineered articular cartilage may succumb to arthritis as well, leaving a patient back at square one, with a painful, diseased synovial joint. This could be a fundamental flaw in tissue-engineered implants for joint replacement, unless a method of protecting the new tissue can be developed.

\section{Manufacture and cost}

Synthetic joint replacement is a well-established procedure for treating diseased synovial joints. It is estimated that over one million synthetic implants for hip and knee replacements are implanted worldwide per year (Theta reports 1998). Conventional manufacturing processes such as casting, forging and machining are used to manufacture the synthetic implants at reasonable cost. In the UK a synthetic hip replacement implant typically costs between $f^{3} 300$ and $f_{2} 2000$ (National Audit Office 2000). The total cost of the surgical procedure is in the range of $£ 2300$ to f7500 (National Audit Office 2003).

If tissue engineering is going to be a major healthcare treatment of the future and replace the use of some synthetic implants, production scale tissue engineering, producing thousands of implants a month will be required (Nerem 2000; Temenoff and Mikos 2000). Since 1987 around 20,000 procedure have taken place using autologous chondrocyte transplantation (Brittberg 2007), yet the total for joint replacement of the hip and knee is around one million per year (Theta reports 1998), so there would be potentially many patients that could benefit from a successful tissue engineering technique for articular cartilage. It is difficult to imagine that production scale tissue engineering could be possible if each tissue-engineered implant has to be made from cells from the individual patient. Estimated costs for autologous chondrocyte transplantation in the United States range from $\$ 17,000$ to $\$ 38,000$ (Minas and Peterson 2000). Although this is comparable to costs for total joint replacement implants, in the United States, any new articular cartilage defects would require a further transplantation.

Ideally, an off-the-shelf tissue-engineered implant would be required. This leads to one of the most controversial issues that will have to be addressed in tissue engineering: the use of stem cells. These cells have yet to differentiate which means that potentially they can be manipulated to produce any tissue (Lalan et al. 2001). Stem cell research has been controversial since the cells are obtained from human embryos (Ringe et al. 2002). However, stem cells derived from human adult tissues have now been identified as an alternative. For example, bone marrow derived stem cells can differentiate into bone and articular cartilage (Ringe et al. 2002; Gao et al. 2007). The advantage of using these cells is that they are well tolerated immunologically and hence could be made available on a commercial basis (Hunziker 2002).

The development and health of articular cartilage is greatly influenced by the mechanical forces that it is subjected to. For its health articular cartilage relies on nutrients in the synovial fluid, which enter and leave the cartilage during loading and unloading of the joint (Temenoff and Mikos 2000). Further, it has been proposed that articular 
cartilage becomes conditioned to the prevalent loading conditions to which it is subjected (Yao and Seedhom 1992; Shepherd and Seedhom 1999a). With regards to tissueengineered articular cartilage, it would imply that in order to be weight-bearing in the body, cartilage would need to be subjected to loading before it is implanted in the human body to enable it to be conditioned to the likely loading conditions. If cartilage cells are simply grown and then implanted into the body, they might not survive the loading conditions. Thus, bioreactors that grow, maintain and subject cartilage to physiological loading conditions will be required and there is current research in the area (Mauck et al. 2000; Demarteau et al. 2003; Saini and Wick 2003; Yoshioka et al. 2007). A number of studies have shown that compressive loading of tissue contracts leads to enhanced formation and stiffer tissue (Hung et al. 2004; Waldman et al. 2004).

To manufacture tissue-engineered implants involves many more manufacturing stages than conventional synthetic implant and, therefore, at present the manufacturing costs are generally high. As the technology of tissue engineering advances, the costs will decrease (Atala 2004).

\section{Fixation}

Fixation of synthetic joint replacement implants have been successfully achieved by a number of methods: bone cement, interference fit and bone ingrowth. The optimum method of fixation for a tissue-engineered scaffold/cell assembly will need to be determined. Synthetic implants have a major advantage that early mobilisation and weight bearing can be achieved quickly after surgery. With tissueengineered articular cartilage, full weight bearing is not allowed until around 8 weeks after implantation (Bailey et al. 2003), to enable the cells integrate with existing tissue.

\section{Intervention}

Tissue-engineered joint replacement implants need early intervention, that is much before the disease has progressed too far and destroyed most of the articular cartilage surface. At present, it is being used to treat small defects (Richardson et al. 1999), whereas synthetic implants are used to treat extensive destruction of the joint surface. Synthetic implants are also used where there is severe deformity and damage to other soft tissues, such as bone and ligaments. For example, in a knee joint affected by rheumatoid arthritis there can be damage to the ligaments (Hart et al. 2004). Some designs of total knee replacement are for use where cruciate ligaments are not required (Fuchs et al. 2004). If tissue engineering is to be used in the absence of functioning ligaments, tissue-engineered ligaments, as well as tissue-engineered articular cartilage, would also be required. Although there is research in the area of tissue-engineered ligaments, as with all tissueengineered constructs, there are many limitations still to be addressed (Van Eijk et al. 2004; Vunjak-Novakovic et al. 2004).

\section{Tribology}

Natural synovial joints have excellent tribological properties that allow joints to operate for a lifetime, in the absence of disease. Under some conditions during the gait cycle (high velocity, low load) synovial joints can operate with fluid film lubrication (Dowson and Jin 1986; Unsworth 1991; Murakami et al. 1998). However, under severe loading conditions, or where there is little motion, fluid films are unlikely to persist and, therefore, boundary or mixed lubrication will occur (Murakami et al. 1998). With the use of tissue-engineered implants, there is the possibility to restore the natural articular cartilage joint surface and, therefore, gain the excellent tribological properties of the natural joint.

Metal-on-polymer joint replacement implants operate with a boundary or mixed lubrication regime, where the bearing surfaces are not separated by a fluid film and, therefore, wear can occur (Murakami et al. 1998; Dowson 2001). Few metal-on-polymer implants can be expected to last for 25 years due to wear of the polymer, therefore, this type of implant is not suitable for the young or very active since after they have been implanted for a number of years revision surgery would be required. Wear can cause structural failure of the polymer and altered biomechanics if the shape of the polymer implant becomes changed by wear (Fisher 1994). The most serious problem from wear of the polymer is osteolysis, where an adverse cellular reaction leads to bone resorption and implant loosening (Ingham and Fisher 2000). The problem with polymer wear has lead to the consideration of alternative articulating material combinations, such as metal-on-metal, ceramic-onceramic or ceramic-on-metal, in an attempt to reduce wear debris (Dowson 2001; Sedel and Raould 2007; Vassiliou et al. 2007). Although these alternative material combinations have been shown to have reduced wear debris compared with metal-on-polymer implants, wear debris still occurs.

\section{Regulation}

Before conventional synthetic medical devices can be implanted into patients, they must meet the necessary regulations, such as the European Medical Device Directive (Shepherd 2002) or in the United States, the regulations of the Food and Drug Administration (Eidenberger 2000). One of the essential parts of developing a medical device is to undertake a risk analysis to help identify any potential hazards associated with its use (Shepherd 2002). Clearly, with tissue-engineered implants there will be many potential new hazards introduced, such as new diseases or contamination of the cells, and legislation for these types of implants is being developed (Moore 2002; Williams 2007), e.g. ASTM F2312 (ASTM 2004).

\section{CONCLUSIONS}

This paper has compared the relative merits of synthetic and tissue-engineered implants for joint replacement, 
although the points raised are equally applicable for implants used in any part of the human body. Joint replacement with synthetic materials is a well-established procedure with the advantages being early mobilisation, pain relief and high patient satisfaction. However, synthetic implants are not natural tissues and can cause adverse reactions from the body (particularly from wear debris). Further, there is a mismatch in mechanical properties compared to natural tissues. Tissue-engineered implants offer great potential and have the major advantage over synthetic implants that it is natural tissue, which should ensure that it is totally biocompatible, have the correct mechanical properties and integrate well with the existing tissue. However, people should not get carried away with tissue engineering before the basic science has been fully understood (Lalan et al. 2001; Rose and Oreffo 2002). There are still many limitations to be addressed in tissue engineering such as scaling up for production, bioreactor design, appropriate regulation and the potential for disease to attack the new tissue-engineered implant.

\section{ACKNOWLEDGEMENTS}

The authors thank Professor David W.L. Hukins for his helpful comments on the draft manuscript.

\section{REFERENCES}

ASTM F2312-04. 2004. Standard Terminology Relating to Tissue Engineered Medical Products. West Conshohocken: American Society for Testing and Materials.

Atala A. 2004. Tissue engineering and regenerative medicine: Concepts for clinical application. Rejuv Res, 7:15-31.

Bailey A, Goodstone N, Roberts S, et al. 2003. Rehabilitation after Oswestry autologous-chondrocyte implantation: the OsCell protocol. 7 Sport Rehabil, 12:104-18.

Beevers DJ, Seedhom BB. 1993. Metacarpophalangeal joint prostheses: A review of past and current designs. Proc Inst Mech Eng Part H: $\mathcal{F}$ Eng Med, 207:195-206.

Bergmann G, Deuretzbacher G, Heller M, et al. 2001. Hip contact forces and gait patterns from routine activities. 7 Biomech, 34:859-71.

Behrens P, Bitter T, Kurz B, et al. 2006. Matrix-associated autologous chondrocyte transplantation/implantation (MACT/MACI) - 5-year follow-up. Knee, 13:194-202.

Berry DJ, Harmsen WS, Cabanela ME, et al. 2002.

Twenty-five-year survivorship of two thousand consecutive primary Charnley total hip replacements - Factors affecting survivorship of acetabular and femoral components. $\mathcal{F}$ Bone Foint Surg Am, 84A:171-7.

Berthiaume F, Yarmush ML. 2000. Tissue engineering. In: The Biomedical Engineering Handbook, Chapter 109, Bronzino JD, ed., Boca Raton, FL: CRC Press, p. 1-12.

Brittberg M. 2007. Articular cartilage engineering with autologous chondrocyte transplantation. In: European Musculoskeletal Review 2007. London: Touch Briefings, p. 81-4.

Brittberg M, Lindahl A, Nilsson A, et al. 1994. Treatment of deep cartilage defects in the knee with autologous chondrocyte transplantation. New Engl 7 Med, 331:889-95.
Costigan PA, Deluzio KJ, Wyss UP. 2002. Knee and hip kinetics during normal stair climbing. Gait Posture, 16:31-7.

Daniel J, Pynsent PB, McMinn DJW. 2004. Metal-on-metal resurfacing of the hip in patients under the age of 55 years with osteoarthritis. 7 Bone foint Surg Br, 86B:17784.

Demarteau O, Jakob M, Schafer D, et al. 2003. Development and validation of a bioreactor for physical stimulation of engineered cartilage. Biorheology, 40:331-6.

Dieppe PA, Doherty M, Macfarlane D, et al. 1985a. Rheumatoid arthritis. In: Rheumatological Medicine. New York: Churchill Livingstone p. 41-64.

Dieppe PA, Doherty M, Macfarlane D, et al. 1985b. Osteoarthritis. In: Rheumatological Medicine. New York: Churchill Livingstone, p. 145-56.

Dowson D. 2001. New joints for the millennium: Wear control in total replacement hip joints. Proc Inst Mech Eng Part H: 7 Eng Med, 215:335-58.

Dowson D, Jin ZM. 1986. Micro-elastohydrodynamic lubrication of synovial joints. Eng Med, 15:63-5.

Eidenberger R. 2000. Medical device registration, agreements on mutual recognition - A step forward to global harmonization? Radiat Phys Chem, 57:539-42.

Fisher F. 1994. Wear of ultra high molecular weight polyethylene in total artificial joints. Curr Orthop, 8:164-9.

Frenkel SR, Di Cesare PE. 2004. Scaffolds for articular cartilage repair. Ann Biomed Eng, 32:26-34.

Fuchs S, Tibesku CO, Genkinger M, et al. 2004. Clinical and functional comparison of bicondylar sledge prostheses retaining all ligaments and constrained total knee replacement. Clin Biomech, 19:263-9.

Gao J, Yao JQ Caplan AI. 2007. Stem cells for tissue engineering of articular cartilage. Proc Inst Mech Eng Part H: F Eng Med, 221:441-50.

Hart DA, Kydd AS, Frank CB, et al. 2004. Tissue repair in rheumatoid arthritis: Challenges and opportunities in the face of a systemic inflammatory disease. Best Pract Res $\mathrm{Cl} \mathrm{Rh}$, 18:187-202.

Hukins DWL, Leahy JC, Mathias KJ. 1999. Biomaterials: Defining the mechanical properties of natural tissues and selection of replacement materials. 7 Mater Chem, 9:629-36.

Hung CT, Mauck RL, Wang CCB, et al. 2004. A paradigm for functional tissue engineering of articular cartilage via applied physiologic deformational loading. Ann Biomed Eng, 32:35-49.

Hunziker EB. 2002. Articular cartilage repair: basic science and clinical progress - A review of the current status and prospects. Osteoarthritis Cart, 10:432-63.

Hutmacher DW. 2000. Scaffolds in tissue engineering bone and cartilage. Biomaterials, 21:2529-43.

Ingham E, Fisher J. 2000. Biological reactions to wear debris in total joint replacement. Proc Inst Mech Eng Part H: 7 Eng Med, 214:21-37.

Joshi MG, Advani SG, Miller F, et al. 2000. Analysis of a femoral hip prosthesis designed to reduce stress shielding. 7 Biomech, 33:1655-62.

Joyce EJ, Unsworth A. 2000. The design of a finger wear simulator and preliminary results. Proc Inst Mech Eng Part H: $\mathcal{F}$ Eng Med, 214:519-26.

Kielpinski G, Prinzi S, Duguid J, et al. 2005. Roadmap to approval: Use of an automated sterility test method as a lot release test for Carticel, autologous cultured chondrocytes. Cytotherapy, 7:531-41. 
Lalan S, Pomerantseva I, Vacanti JP. 2001. Tissue engineering and its potential impact on surgery. World 7 Surg. 25:1458-66.

Lee SH, Shin H. 2007. Matrices and scaffolds for delivery of bioactive molecules in bone and cartilage tissue engineering. Adv Drug Deliv Rev, 59:339-59.

Lysaght MJ, Nguy NAP, Sullivan K. 1998. An economic survey of the emerging tissue engineering industry. Tissue Eng. 4:2318.

Manfredini M, Zerbinati F, Gildone A, et al. 2007. Autologous chondrocyte implantation: a comparison between an open periosteal-covered and an arthroscopic matrix-guided technique. Acta Orthop Belg, 73:207-18.

Martin I, Miot S, Barbero A, et al. 2007. Osteochondral tissue engineering. 7 Biomech, 40:750-65.

Mauck RL, Soltz MA, Wang CCB, et al. 2000. Functional tissue engineering of articular cartilage through dynamic loading of chondrocyte-seeded agarose gels. 7 Biomech Eng-T ASME, 122:252-60.

McMinn D, Daniel J. 2006. History and modern concepts in surface replacement. Proc Inst Mech Eng Part H: F Eng Med, 220:239-51.

Micheli LJ, Moseley JB, Anderson AF, et al. 2006. Articular cartilage defects of the distal femur in children and adolescents: Treatment with autologous chondrocyte implantation. 7 Pediatr Orthop, 26:455-60.

Minas T, Peterson L. 2000. Autologous chondrocyte transplantation. Oper Tech Sport Med, 8:144-57.

Moore R. 2002. Standards in the 21st century: Standardising new medical technologies. Med Device Technol, 13:44-5.

Murakami T, Higaki H, Sawae Y, et al. 1998. Adaptive multimode lubrication in natural synovial joints and artificial joints. Proc Inst Mech Eng Part H: 7 Eng Med, 212:23-35.

National Audit Office. 2000. Hip Replacements: Getting It Right First Time. London: The stationary Office. URL: http://www.nao.org.uk/publications/nao_reports/9900417.pdf

National Audit Office. 2003. Hip Replacements: An Update. London: The stationary Office. URL:

http://www.nao.org.uk/publications/nao_reports/0203/0203956.pdf

Nehrer S, Domayer S, Dorotka R, et al. 2006. Three-year clinical outcome after chondrocyte transplantation using a hyaluronan matrix for cartilage repair. Eur $\mathcal{F}$ Radiol, 57:3-8.

Nerem RM. 2000. Tissue engineering: confronting the transplantation crisis. Proc Inst Mech Eng Part H: 7 Eng Med, 214:95-9.

Nesic D, Whiteside R, Brittberg M, et al. 2006. Cartilage tissue engineering for degenerative joint disease. Adv Drug Deliv Rev, 58:300-22.

Orbell S, Espley A, Johnston M, et al. 1998. Health benefits of joint replacement surgery for patients with osteoarthritis: prospective evaluation using independent assessments in Scotland. 7 Epidemiol Commun H, 52:564-70.

Park JB. 2000. Hip joint prosthesis fixation problems and possible solutions. In Bronzino JD, ed. In: The Biomedical Engineering Handbook, Chapter 46. Boca Raton, FL: CRC Press, p. 1-21.

Park SH, Llináa A, Goel VK, et al. 2000. Hard tissue replacements. In Bronzino JD, ed. In: The Biomedical Engineering Handbook, Chapter 44. Boca Raton, FL: CRC Press, p. 1-35.

Richardson JB, Caterson B, Evans EH, et al. 1999. Repair of human articular cartilage after implantation of autologous chondrocytes. F Bone Foint Surg Br. 81B:1064-8.
Ringe J, Kaps C, Burmester GR, et al. 2002. Stem cells for regenerative medicine: Advances in the engineering of tissues and organs. Naturmissenschaften, 89:33851.

Rose FRAJ, Oreffo ROC. 2002. Bone tissue engineering: Hope vs hype. Biochem Biophys Res Commun, 292:1-7.

Saini S, Wick TM. 2003. Concentric cylinder bioreactor for production of tissue engineered cartilage: Effect of seeding density and hydrodynamic loading on construct development. Biotechnol Prog, 19:510-21.

Sedel L, Raould A. 2007. Engineering aspect of alumina on alumina hip prosthesis. Proc Inst Mech Eng Part H: $\mathcal{F}$ Eng Med, 221:21-7.

Seedhom BB, Luo ZJ, Goldsmith AJ, et al. 2007. In-situ engineering of cartilage repair: A pre-clinical in-vivo exploration of a novel system. Proc Inst Mech Eng Part H: $\mathcal{7}$ Eng Med, 221:475-88

Seedhom BB, Wallbridge NC. 1985. Walking activities and wear of prostheses. Ann Rheum Dis, 44:838-43.

Shepherd DET. 2002. Risk analysis for a radio-carpal joint replacement. Proc Inst Mech Eng Part H: J Eng Med, 216:23-9.

Shepherd DET, Johnstone AJ. 2002. Design considerations for a wrist implant. Med Eng Phys, 24:641-50.

Shepherd DET, Seedhom BB. 1997. Technique for measuring the compressive modulus of articular cartilage under physiological loading rates with preliminary results. Proc Inst Mech Eng Part H: 7 Eng Med, 211:155-65.

Shepherd DET, Seedhom BB. 1999a. The 'instantaneous' compressive modulus of human articular cartilage in joints of the lower limb. Rheumatology, 38:124-32.

Shepherd DET, Seedhom BB. 1999b. Thickness of human articular cartilage in joints of the lower limb. Ann Rheum Dis, 58:27-34.

Temenoff JS, Mikos AG. 2000. Review: Tissue engineering for regeneration of articular cartilage. Biomaterials, 21:43140.

Theta reports. 1998. World orthopedic implants market. New York: PJB Medical Publications.

Unsworth A. 1991. Tribology of human and artificial joints. Proc Inst Mech Eng Part H: $\mathcal{F}$ Eng Med, 205:163-72.

van der Kraan PM, Buma P, Kuppevelt van T, et al. 2002. Interaction of chondrocytes, extracellular matrix and growth factors: Relevance for articular cartilage tissue engineering. Osteoarthritis Cart, 10:631-7.

Van Eijk F, Saris DBF, Riesle J, et al. 2004. Tissue engineering of ligaments: A comparison of bone marrow stromal cells, anterior cruciate ligament, and skin fibroblasts as cell source. Tissue Eng, 10:893-903.

Vassiliou K, Scholes SC, Unsworth A. 2007. Laboratory studies on the tribology of hard bearing hip prostheses: ceramic on ceramic and metal on metal. Proc Inst Mech Eng Part H: $\mathcal{7}$ Eng Med, 221:11-20.

Vunjak-Novakovic G, Altman G, Horan R, et al. 2004. Tissue engineering of ligaments. Annu Rev Biomed Eng, 6:131-56.

Waldman SD, Spiteri CG, Grynpas MD, et al. 2004. Long-term intermittent compressive stimulation improves the composition and mechanical properties of tissue-engineered cartilage. Tissue Eng, 10:1323-31.

Wood JJ, Malek MA, Frassica FJ, et al. 2006. Autologous cultured chondrocytes: Adverse events reported to the United States Food and Drug Administration. 7 Bone Foint Surg Am. 88A:503-7. 
Williams DF 2007. A European regulatory pathway for tissue engineering - at last. Med Device Technol, 18:8-11.

Yao JQ, Seedhom BB. 1992. Mechanical conditioning of articular cartilage to prevalent stresses. Brf Rheumatol, 32:956-65.
Yoshioka T, Mishima H, Ohyabu Y, et al. 2007. Repair of large osteochondral defects with allogeneic cartilaginous aggregates formed from bone marrow-derived cells using RWV bioreactor. 7 Orthopaed Res, 25:1291-8. 

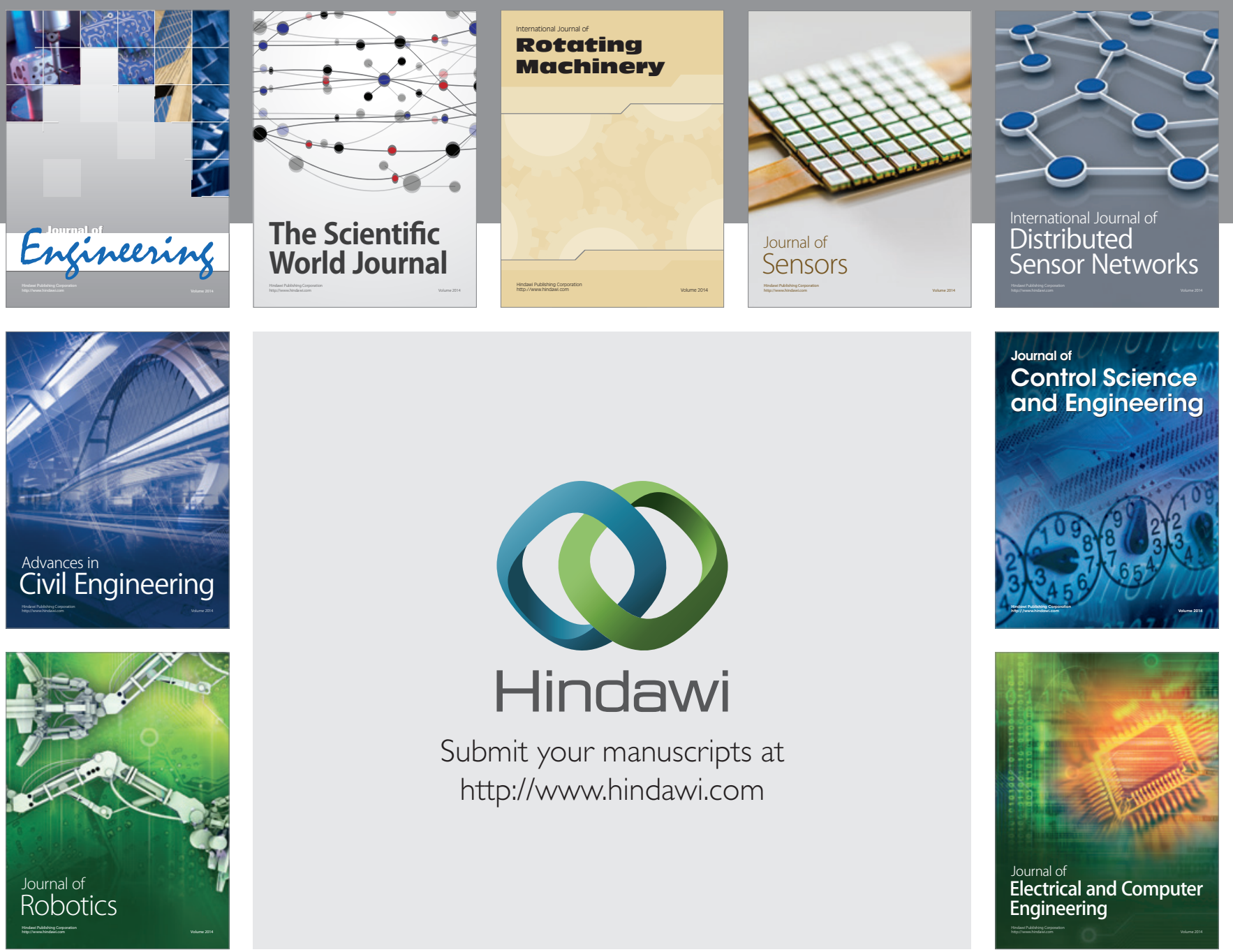

Submit your manuscripts at

http://www.hindawi.com
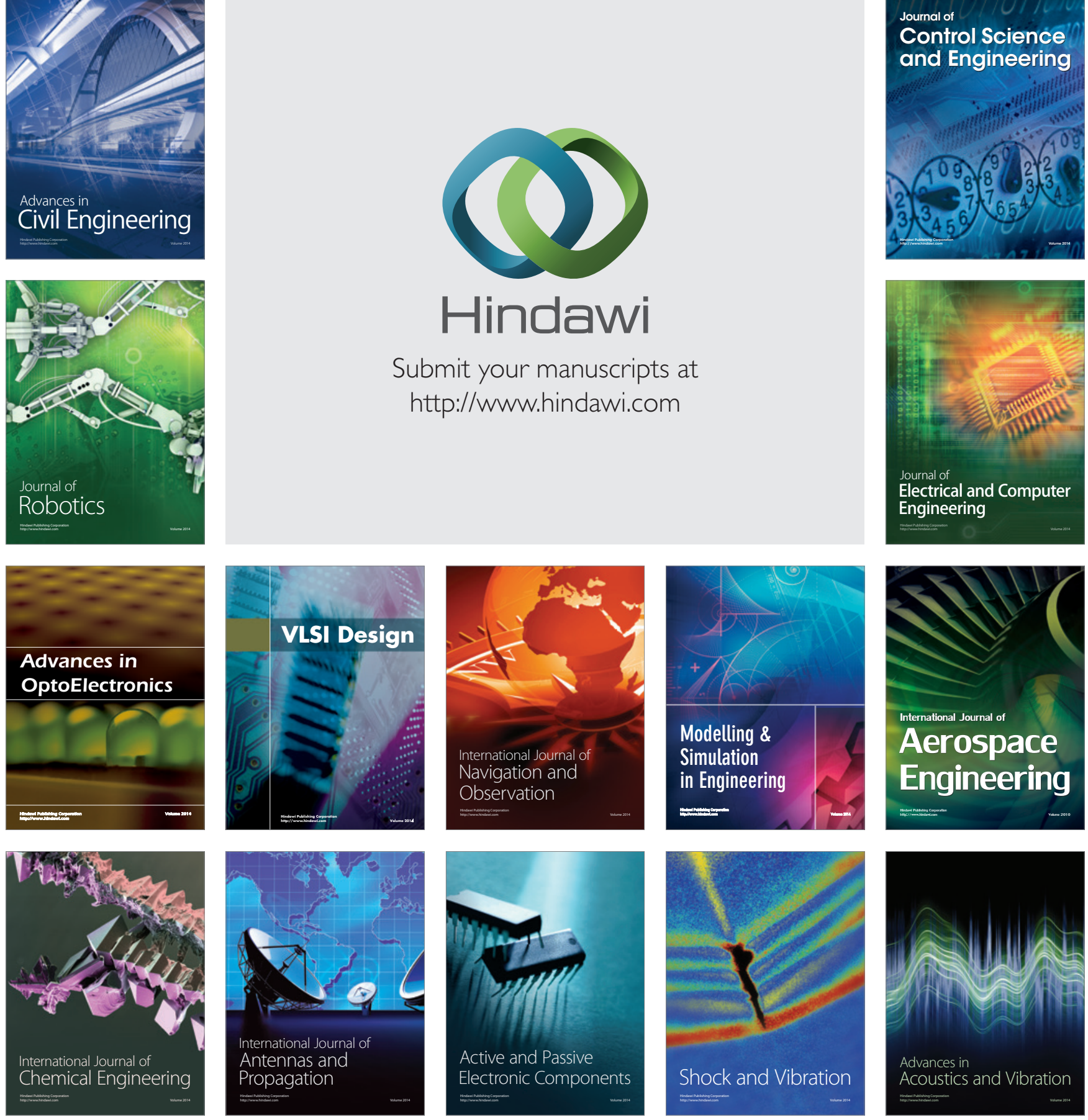